\title{
Management of Crisis of COVID-9 by the Council for Regulation of Engineering in Nigeria (COREN) Benin City, Using Six Sigma Project Management Approach
}

\author{
*KINGSLEY-OMOYIBO, Q; AYEBAKURO, RE \\ Department of Mechanical Engineering, Igbinedion University Okada, Okada Town, Edo State, Nigeria \\ *Corresponding Author Email: queeneth.omoyibo@iuokada.edu.ng, Other Author Email: roland.ayebakuro@iuokada.edu.ng
}

\begin{abstract}
ABSRACT: Effective project management style is extremely important for managing crisis and this strongly contributes to the success of an organization such as COREN. The objective of this study is to assess the management crisis of COVID- 19 by the council for regulation of Engineering in Nigeria (COREN) Benin City, Nigeria using six sigma project management approach with the triangulation design of two phases, Phase 1 using quantitative analysis, descriptive statistics while phase 2 used the qualitative analysis. Final results collected from the merger of phase 1 and phase 2 showed a T-test value of -37.523 at $\mathrm{P}$ value significant of 0.000 obtained for understanding project management as it relates to crisis management during times of extraordinary crisis in the model and was less than $5 \%$ level of significance indicating that there is a significant relationship between Understanding project management as it relates to crisis management to aid organizations in working effectively during times of extraordinary crisis. Process performance was improved to address the root cause of poor crisis management using six sigma styles with $68 \%$ strongly agreeing that proper planning will provide an efficient medium. A one sample T test result of -42.547 , with a $95 \%$ confidence interval of the difference at a lower value of -1.99 and an upper value of -1.81 , showed that the model is reliable with absence of serial auto correlation. A standard deviation of 0.309 showed that $1 \%$ increase in proper understanding of project management styles (six sigma) activities results in $30.9 \%$ decrease in crisis such as COVID 19. Hence using the six sigma style of managing extraordinary crisis has proved to sustain managing crisis and strongly contributes to the success of organizations such as COREN.
\end{abstract}

\section{DOI:https://dx.doi.org/10.4314/jasem.v25i9.28}

Copyright: Copyright $\odot 2021$ Kingsley-Omoyibo and Ayebakuro. This is an open access article distributed under the Creative Commons Attribution License (CCL), which permits unrestricted use, distribution, and reproduction in any medium, provided the original work is properly cited.

Dates: Received: 09 May 2021; Revised: 12 August 2021; Accepted: 12 September 2021

Keywords: COVID-19, Crises Management, triangulation design, engineering process performance

COVID-19 affected businesses everywhere, causing the distribution chain not to be uniform. Businesses that thrived on movement of people and goods airlines, automobiles etc., were the first to feel this impact as several routes both international and local were shut down. Although not facet of industries was affected equally, in as much as some saw a drastic drop in revenue (such as banking firms), some sectors such as the technology sector (commonly referred to as the ICT/IT department) saw a rise in revenue as companies' demand for tech services increased almost exponentially as they focused even more on securing their assets during the troubling times. Establish Communication Protocols Good communication protocols in times of crisis include: whether the business will continue to be functioning throughout the crisis, and if yes, what proportion of the business will remain online? This is particularly important in case there is a lockdown in the area. How will updates be communicated to the client? What will be the tools used for communication, approvals, etc.? What parts of the project should the customer care about? With the issue of unceasing lockdown in most areas, the idea of working from an office is slowly waning as organizations have been compelled to carry out their day-to-day work from the comfort of their homes. The following are ways that can be adopted to achieve a successful remote working experience: The right remote working tools, especially for seamless communication and video. A unified project management tool that gives a complete picture of the entire agency's operations. A culture that promotes transparency, sharing, collaboration, and teamwork over individual brilliance. Protecting staffs and investors alike should be the number one priority, as some are anxious about the investments, some their careers. The following are measures that can be taken to ensure that: Adopting working remotely policies, cutting out all unimportant movements, cutting nonessential expenditures and Slashing salaries of senior staffs, if possible. Jaques (2010) conversed on reshaping crisis management: the challenge for organizational design. A recent methodology to crisis management is developing which advances past a purely volatile response and creates fresh opportunities for improved organizational development. Therefore, the objective of this study is to assess the management crisis of COVID-19 by the 
council for regulation of Engineering in Nigeria (COREN) Benin City, Nigeria using six sigma project management approach with the Triangulation design of two phases.

\section{MATERIALS AND METHODS}

This study employed the concurrent triangulation model. Quantitative and qualitative analysis were explored where the quantitative analysis used questionnaires survey. The in-depth interview method was used to explain the qualitative phase of the model. The concurrent triangulation design is presented.

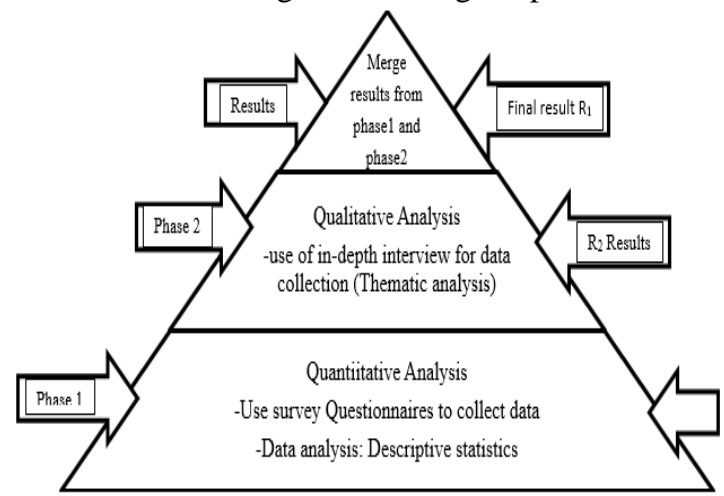

Fig 1: Concurrent triangulation design (source of figure design: Queeneth, Kingsley-Omoyibo, 2020)

Project management officers from COREN office, distributed fifty (50) close ended questions in questionnaires and a total of 48 were found useable. For the second phase, the qualitative analysis was carried out using in-depth interview with a sample size of fifty (50) people. All fifty (50) in-depth interviews conducted were found useable for the analysis. A total of one hundred a (100) responses were analyzed and recorded. Residual statistics was used to validate the model. Understanding project management and how it relates to crisis management for COREN to work effectively was introduced to the sample size as a crisis checker. Engineers and some individuals were given questionnaires with in-depth interviews conducted. Collated results were analyzed and recorded.

\section{RESULTS AND DISCUSSIONS}

From Table 1 and pie charts shown, over $55 \%$ of respondents strongly agreed that a project management officer (PMO) should be flexible with his project management styles( Six sigma)and should consider the safety of his staffs at all times by developing a strong relationship with the Covid-19 medical team. Majority of the respondents also agreed that professionals and multinationals should be more involved in curbing the wide spread of the virus. Also, more than $60 \%$ of respondents strongly agreed that managing the adverse effects of covid-19 as a complex project requires good leadership skills, expertise and professionalism. The ideas of the PMO should be critically considered and presented to the covid-19 team before it is put into action. More than 55\% of respondents strongly agreed to the opinion that PMO's should set up correct planning by providing an efficient medium for delivering critical projects whilst maintaining physical distancing, they should also provide room for work digitalization in the advent of an extraordinary crisis such as covid-19, with corporation of professional bodies like COREN, extraordinary crises such as Covid-19 can be well managed and planned for.

Hypothesis Testing: Two hypotheses have been drawn and tested. For testing these hypotheses, a one sample T-Test of SPSS was used to find correlations between demographic indicators. As regards to hypothesis testing, firstly, each listed hypothesis had different sections in the questionnaires and these sections contain multiple questions which were referred to as indicators. Each indicator was related of the questionnaire. For testing each hypothesis, there is a null hypothesis against an alternative hypothesis. For the null hypothesis $\left(\mathrm{H}_{\mathrm{o}}\right)$, It was supposed that the indicators had not negatively affected the management of the current crisis (covid-19), while for an alternative hypothesis $\left(\mathrm{H}_{1}\right)$,

Table 1: Table showing statistics of in-depth interviews carried out on respondents

\begin{tabular}{|c|c|c|c|c|c|c|c|c|}
\hline \multicolumn{9}{|c|}{ In-depth interview } \\
\hline & $\begin{array}{l}\mathrm{N} \\
\text { Statistic }\end{array}$ & $\begin{array}{l}\text { Range } \\
\text { Statistic }\end{array}$ & $\begin{array}{l}\text { Minimum } \\
\text { Statistic }\end{array}$ & $\begin{array}{l}\text { Maximum } \\
\text { Statistic }\end{array}$ & $\begin{array}{l}\text { Mean } \\
\text { Statistic }\end{array}$ & Std. Error & $\begin{array}{l}\text { Std. Deviation } \\
\text { Statistic }\end{array}$ & $\begin{array}{l}\text { Variance } \\
\text { Statistic }\end{array}$ \\
\hline IDI1 & 50 & 2 & 1 & 3 & 1.42 & .081 & .575 & .330 \\
\hline IDI2 & 50 & 2 & 1 & 3 & 1.48 & .077 & .544 & .296 \\
\hline IDI3 & 50 & 2 & 1 & 3 & 1.52 & .087 & .614 & .377 \\
\hline IDI4 & 50 & 3 & 1 & 4 & 2.02 & .132 & .937 & .877 \\
\hline IDI5 & 50 & 3 & 1 & 4 & 1.48 & .112 & .789 & .622 \\
\hline IDI6 & 50 & 3 & 1 & 4 & 1.58 & .103 & .731 & .534 \\
\hline IDI7 & 50 & 3 & 1 & 4 & 1.44 & .100 & .705 & .496 \\
\hline IDI8 & 50 & 2 & 1 & 3 & 1.46 & .082 & .579 & .335 \\
\hline IDI9 & 50 & 4 & 1 & 5 & 1.56 & .125 & .884 & .782 \\
\hline IDI10 & 50 & 1 & 1 & 2 & 1.42 & .071 & .499 & .249 \\
\hline Valid N (list wise) & 50 & & & & & & & \\
\hline
\end{tabular}


It was supposed that implementing said indicators had positive effect on the management of the current crisis (covid-19). Conclusions were drawn according to the result of the tests; Firstly, if Significant, it is less than 0.05 . Hence the null hypothesis will be rejected, it means that said indicators positively affected the management of the current crisis (covid-19). Secondly, if the mean in the T-Test is less than 3 based on the Likert scale in the questionnaires ( $1=$ strongly agree, 2=agree, 3=disagree, 4=strongly disagree, $5=$ undecided), it meant most of the respondent's answered less than 3 (1=strongly agree, $2=$ agree). Hence the alternative hypothesis will be accepted.

Hypothesis 1: Understanding project management as it relates to crisis management during times of extraordinary crisis: Lack of proper understanding of project management as it relates to crisis management by a PMO or an organization like COREN, may cause massive problems for them which can lead them to incurring unwarranted debt. This hypothesis seeks to find out if understanding project management as it relates to crisis management will aid organizations like COREN to develop an effective working environment for her staff during times of extraordinary crisis or not? Null hypothesis $\left(\mathrm{H}_{\mathrm{o}}\right)$ : Understanding project management as it relates to crisis management will negatively affect organizations in working effectively during times of extraordinary crisis. (Mean $>=3$ ). Alternative hypothesis $\left(\mathrm{H}_{1}\right)$ : Understanding project management as it relates to crisis management will positively affect organizations in working effectively during times of extraordinary crisis. (Mean <3)

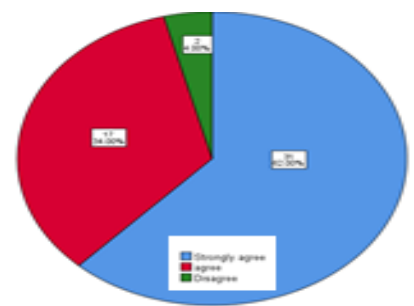

Fig 1: Demographic statistic of a PMO'S flexibility with his project management styles during the crisis. $62 \%$ of the respondents strongly agreed that the Project Management officials should be flexible with project management styles during a crisis.

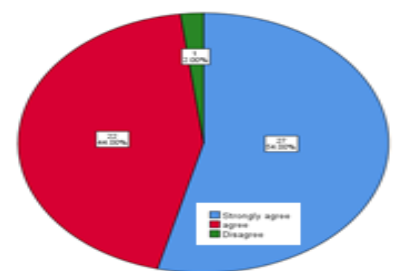

Fig 2: Demographic statistic of a PMO'S safety consciousness of his staffs. $98 \%$ of the respondents agreed with $54 \%$ strongly agreeing and $44 \%$ agreeing to a high level of safety consciousness during an extraordinary crisis. Only $2 \%$ disagree.

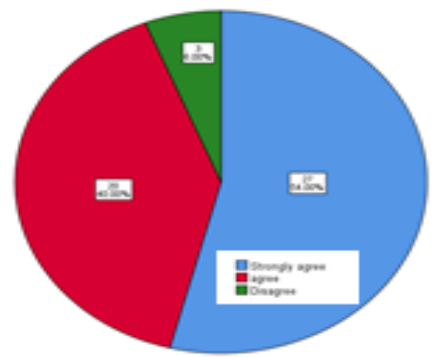

Fig 3: Demographic statistic of a PMO'S solid relationship with the covid-19 medical team

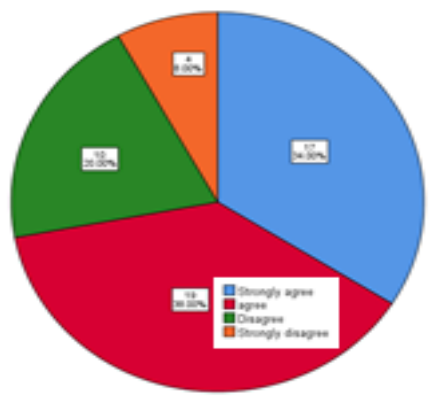

Fig 4: Demographic statistic of involvements of professionals, and multinationals in the fight against covid-19

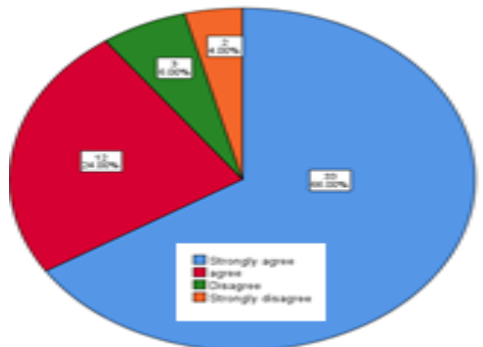

Fig 5: Demographic statistic of good leadership skills as a vital ingredient in managing the adverse effects of covid-1

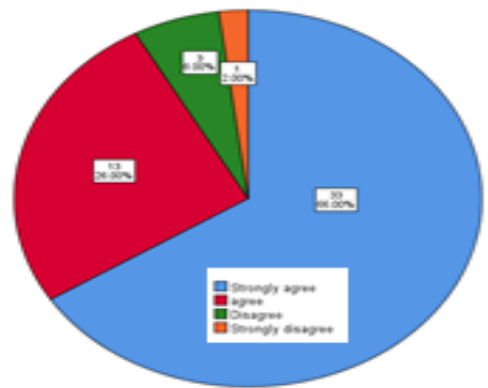

Fig 6: Demographic statistic of expertise/professionalism as a vital ingredient in managing the adverse effects of covid-19

From Table 2, the average significance is 0.00 , since $0.00<0.05$, the null hypothesis (Mean $>=3$ ) will be rejected. Hence the alternative hypothesis $\left(\mathrm{H}_{1}\right)$ will be accepted; meaning that understanding project management as it relates to crisis management will positively affect organizations like COREN in working effectively during times of extraordinary crisis. 


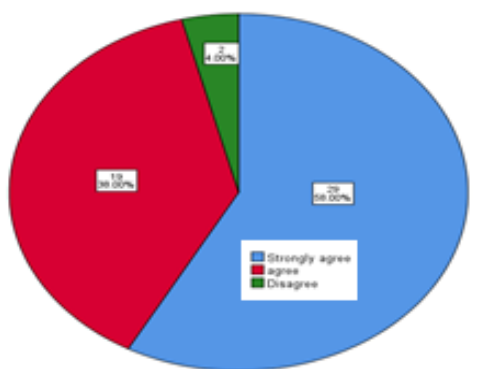

Fig 8: Demographic statistic of critically discussing the PMO'S idea with the covid-19 response team before it is put to action

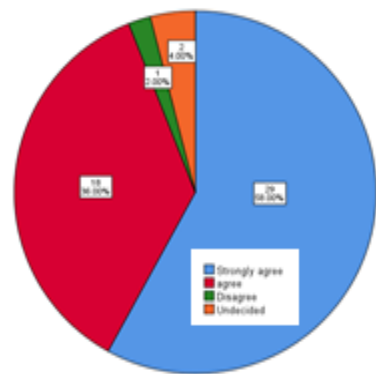

Fig 9: Demographic statistic of providing a room for work digitalization in the advent of an extraordinary crisis such as covid-19

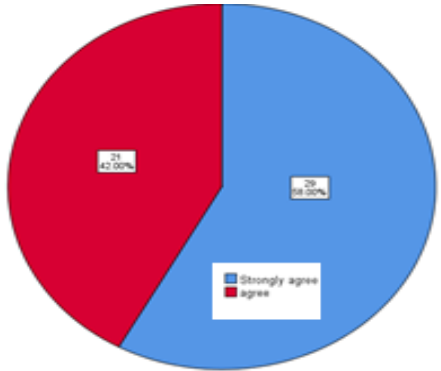

Fig 10: Demographic statistic of corporation of professional bodies like COREN and PMO's in managing and planning for an extraordinary crisis such as covid-19
Hypothesis 2: Establishing ways to identify crisis, assess crisis, handle crisis, and manage extraordinary crisis by organizations like COREN: Failing to establish lockdown measures in managing crises by organizations such as COREN may result in devastating consequences, in the sense that both staff and activities might be halted as a result of negligence Establishing ways to identify, assess, handle, and manage extraordinary crisis should they arise, will assist organizations like COREN to manage crisis to suppress its adverse effects or will not? Null hypothesis $\left(\mathrm{H}_{\mathrm{o}}\right)$ : Establishing ways to identify, assess, handle, and manage extraordinary crisis should they arise will not assist organizations like COREN to manage crisis to suppress its adverse effects (Mean $>=3$ ). Alternative hypothesis $\left(\mathrm{H}_{1}\right)$ : Establishing ways to identify, assess, handle, and manage extraordinary crisis should they arise will assist organizations like COREN to manage crisis to suppress its adverse effects $($ Mean $<3$ ).

Table 2: One sample T-Test of hypothesis 1

\begin{tabular}{lllll}
\hline \multicolumn{5}{c}{ One-Sample Statistics } \\
\hline & $\mathrm{N}$ & Mean & $\begin{array}{l}\text { Std. } \\
\text { Deviation }\end{array}$ & $\begin{array}{l}\text { Std. Error } \\
\text { Mean }\end{array}$ \\
\hline CMC1 & 50 & 1.02 & .141 & .020 \\
CMC2 & 50 & 1.04 & .198 & .028 \\
CMC3 & 50 & 1.14 & .351 & .050 \\
CMC4 & 50 & 1.24 & .431 & .061 \\
CMC5 & 49 & 1.04 & .200 & .029 \\
CMC6 & 46 & 1.02 & .147 & .022 \\
CMC7 & 46 & 1.02 & .147 & .022 \\
CMC8 & 40 & 1.13 & .335 & .053 \\
\hline
\end{tabular}

\begin{tabular}{|c|c|c|c|c|c|c|}
\hline \multicolumn{7}{|c|}{ One-Sample Test } \\
\hline & \multicolumn{6}{|c|}{ Test Value $=3$} \\
\hline & \multirow[t]{2}{*}{$\mathrm{T}$} & \multirow[t]{2}{*}{$\mathrm{df}$} & \multirow{2}{*}{$\begin{array}{l}\text { Sig. (2- } \\
\text { tailed) }\end{array}$} & \multirow{2}{*}{$\begin{array}{l}\text { Mean } \\
\text { Difference }\end{array}$} & \multicolumn{2}{|c|}{$95 \%$ Confidence Interval of the Difference } \\
\hline & & & & & Lower & Upper \\
\hline CMC1 & -99.000 & 49 & .000 & -1.980 & -2.02 & -1.94 \\
\hline CMC2 & -70.015 & 49 & .000 & -1.960 & -2.02 & -1.90 \\
\hline CMC3 & -37.523 & 49 & .000 & -1.860 & -1.96 & -1.76 \\
\hline $\mathrm{CMC} 4$ & -28.847 & 49 & .000 & -1.760 & -1.88 & -1.64 \\
\hline CMC5 & -68.601 & 48 & .000 & -1.959 & -2.02 & -1.90 \\
\hline CMC6 & -91.000 & 45 & .000 & -1.978 & -2.02 & -1.93 \\
\hline CMC7 & -91.000 & 45 & .000 & -1.978 & -2.02 & -1.93 \\
\hline CMC8 & -35.406 & 39 & .000 & -1.875 & -1.98 & -1.77 \\
\hline
\end{tabular}

Table 3: One sample T-Test of hypothesis 2

\begin{tabular}{lclll}
\hline \multicolumn{5}{c}{ One-Sample Statistics } \\
\hline & $\mathrm{N}$ & Mean & $\begin{array}{l}\text { Std. } \\
\text { Deviation }\end{array}$ & $\begin{array}{l}\text { Std. Error } \\
\text { Mean }\end{array}$ \\
\hline LMOE1 & 48 & 1.10 & .309 & .045 \\
LMOE2 & 46 & 1.02 & .147 & .022 \\
LMOE3 & 45 & 1.07 & .252 & .038 \\
LMOE4 & 39 & 1.05 & .223 & .036 \\
LMOE5 & 47 & 1.04 & .204 & .030 \\
LMOE6 & 45 & 1.09 & .288 & .043 \\
\hline
\end{tabular}




\begin{tabular}{|c|c|c|c|c|c|c|}
\hline \multicolumn{7}{|c|}{ One-Sample Test } \\
\hline & \multicolumn{6}{|c|}{ Test Value $=3$} \\
\hline & \multirow[t]{3}{*}{$\mathrm{T}$} & \multirow[t]{3}{*}{$\mathrm{df}$} & \multirow{3}{*}{$\begin{array}{l}\text { Sig. (2- } \\
\text { tailed) }\end{array}$} & \multirow{3}{*}{$\begin{array}{l}\text { Mean } \\
\text { Difference }\end{array}$} & \multirow{2}{*}{\multicolumn{2}{|c|}{$\begin{array}{l}95 \% \text { Confidence } \\
\text { Interval of the } \\
\text { Difference }\end{array}$}} \\
\hline & & & & & & \\
\hline & & & & & Lower & Upper \\
\hline LMOE1 & -42.547 & 47 & .000 & -1.896 & -1.99 & -1.81 \\
\hline LMOE2 & -91.000 & 45 & .000 & -1.978 & -2.02 & -1.93 \\
\hline LMOE3 & -51.412 & 44 & .000 & -1.933 & -2.01 & -1.86 \\
\hline LMOE4 & -54.461 & 38 & .000 & -1.949 & -2.02 & -1.88 \\
\hline LMOE5 & -65.773 & 46 & .000 & -1.957 & -2.02 & -1.90 \\
\hline LMOE6 & -44.545 & 44 & .000 & -1.911 & -2.00 & -1.82 \\
\hline
\end{tabular}

From Table 4 , the average significance is 0.00 , since $0.00<0.05$, the null hypothesis (mean $>=3$ ) will be rejected. Hence, the alternative hypothesis $\left(\mathrm{H}_{1}\right)$ will be accepted; meaning that establishing ways to identify, assess, handle, and manage extraordinary crisis should they arise will not assist organizations like COREN to manage crisis to suppress its adverse effects.

Table 4: Findings of research hypothesis results

\begin{tabular}{|c|c|c|c|}
\hline Hypothesis & Hypothesis Test & Significant. & Result \\
\hline $\begin{array}{l}\text { Hypothesis } \\
1\end{array}$ & $\begin{array}{l}\text { Understanding project } \\
\text { management as it relates to crisis } \\
\text { management will positively affect } \\
\text { organizations in working } \\
\text { effectively during times of } \\
\text { extraordinary crisis. }\end{array}$ & $<0.05$ & SUPPORTED \\
\hline $\begin{array}{l}\text { Hypothesis } \\
2\end{array}$ & $\begin{array}{l}\text { Establishing ways to identify, } \\
\text { assess, handle, and manage } \\
\text { extraordinary crisis should they } \\
\text { arise will assist organizations like } \\
\text { COREN to manage crisis to } \\
\text { suppress its adverse effects }\end{array}$ & $<0.05$ & SUPPORTED \\
\hline
\end{tabular}

Conclusion For the effective implementation of project management styles such as the six sigma style, the major thing to remember is: a project manager should be flexible with his project management styles. A Project Management Officer (PMO), should always put the safety of his colleagues first at all times, and develop good leadership skills to be applied in managing the adverse effects of covid-19 as a complex project requires expertise and professionalism. Using the six sigma approach of managing extraordinary crisis, there is sustainability in managing crisis as it strongly contributes to the success of organizations such as COREN. Lockdown measures in managing crises by organizations such as COREN were established and it helped to prevent devastating consequences, in the sense that both staff and activities were not halted and negligence was avoided. Established ways to identify, assess, handle, and manage extraordinary crisis should they arise, were recorded to assist organizations like COREN to manage crisis to suppress its adverse effects.

\section{REFERENCES}

Bakir, C (2020). The Turkish state's responses to existential COVID-19 crisis. J.Policy and Society, 39(3): 424-441.
Benson, NM; Öngür, D.; Hsu, J. (2020). COVID-19 testing and patients in mental health facilities. J.The Lancet Psychiatry, 7(6): 476-477.

Burgner, A.; Ikizler, TA; Dwyer, JP. (2020). COVID19 and the inpatient dialysis unit: Managing resources during contingency planning precrisis. Clin. J. Ame. Sty. Nephr., 15(5): 720-722.

Christensen, T.; Andreas Danielsen, OL; Laegreid, P; Rykkja, SE. (2016). Comparing coordination structures for crisis management in six countries. Inter. J. Pub. Admin, 94(2): 316-332.

Covid, CD. C.; Team R. (2020). Severe outcomes among patients with coronavirus disease 2019 (COVID-19) - United States, February 12-March 16, 2020. MMWR Morb Mortal Weekly Rep, 69(12):343-346.

De Natale, G; Ricciardi, V; De Luca, G.; De Natale, D.; Di Meglio, G.; Ferragamo, A; Spina, E. (2020). The COVID-19 infection in Italy: a statistical study of an abnormally severe disease. J. Clinical Medicine, 9(5):1564.-1574.

Falato,A.;Goldstein,I.; Hortaçsu, A. (2020). Financial fragility in the COVID-19 crisis: The case of 
investment funds in corporate bond markets (No. w27559). National Bureau of Economic Research.

Fry, CV; Cai, X.; Zhang, Y; Wagner, C. (2020). Consolidation in a Crisis: Patterns of International Collaboration in COVID-19 Research. Available at SSRN 3595455.

Gondauri, D.; Mikautadze, E.; Batiashvili, M. (2020). Research on COVID-19 Virus Spreading Statistics based on the Examples of the Cases from Different Countries. Electr. J.Gen. Med. 17(4): 209.

Görlich, D.; Stein-Zalai, J. (2020). Reinvigorating multilateral cooperation during the COVID-19 crisis: Opportunities and difficulties. KIELER BEITRÄGE ZUR, 81.

Habersaat, KB, Betsch, C., Danchin, M., Sunstein, CR., Böhm, R., Falk, A.; Fischer, EF. (2020). Ten considerations for effectively managing the COVID-19 transition. Nature human behaviour, $1-11$.

Hoffmann Pfrimer, M.; Barbosa Jr, R. (2020). Brazil's war on COVID-19: Crisis, not conflict-Doctors, not generals. Dialogues in Human Geography, 2043820620924880.

Hoseinpour Dehkordi, A.;Alizadeh, M.,;Derakhshan, P.; Babazadeh, P ;Jahandideh, A. (2020). Understanding epidemic data and statistics: A case study of COVID-19. J. Med. Vir. 38(5):121131.
Jaques, T. (2010). Reshaping crisis management: The challenge for organizational design. Org. Dev.J., 28(1), 98-109.

Jouzdani, J. (2020). Fight against COVID-19: A global outbreak response management performance view. J. Proj. Mange 5(3): 151-156.

Kienzle, J.; Guelfi, N.; Mustafiz, S. (2010). Crisis management systems: a case study for aspectoriented modeling. In Transactions on aspectoriented software development VII (pp. 1-22). Springer, Berlin, Heidelberg.

Lima, NT; Buss, PM.; Paes-Sousa, R. (2020). COVID19 pandemic: a health and humanitarian crisis. Cade. de Saúde Pública, 36, e00177020.

Lippi, G.; Plebani, M. (2020). The critical role of laboratory medicine during coronavirus disease 2019 (COVID-19) and other viral outbreaks. Clinical Chem. Lab. Med. (CCLM), 1.

Liu, Q.; Luo, D.; Haase, J.E.; Guo, Q.; Wang, XQ.; Liu, S.; Yang, BX. (2020). The experiences of health-care providers during the COVID-19 crisis in China: a qualitative study. J.The Lancet Global Health.

Mascio, FD, Natalini, A; Cacciatore, F. (2020). Public Administration and Creeping Crises: Insights from COVID-19 Pandemic in Italy. The American.Rev. Pub. Admin, 50(6-7): 621-627.

Menoni, S.; Schwarz, R. (2020). Recovery during a crisis: facing the challenges of risk assessment and resilience management of COVID19. J.Envir. Sys. and Deci., 1(1):1-10. 